\title{
Examining the Structural Relationships of Service Recovery, Customer Satisfaction and Image in Online Retailing
}

\author{
Suresh Kandulapati \\ School of Management Studies, University of Hyderabad, India \\ Email: hcu.ksuresh@gmail.com (Corresponding Author) \\ Raja Shekhar Bellamkonda \\ School of Management Studies, University of Hyderabad, India \\ Email: brsmsuh@gmail.com
}

\begin{abstract}
This study proposes and tests a structural model to examine the interrelationships among service recovery, customer satisfaction and image in the context of online retailing in India. The study adopts and validates E-RecS-QUAL scale to measure online service recovery. Factor analysis and structural equation modelling (using SPSS and Amos) are applied to test application of the proposed model. Analysis of an online survey data from 140 online retail customers reveals that the service recovery has a significant direct and indirect effect on both customer satisfaction and image. The study highlights mediating role of customer satisfaction in the relationship between online service recovery and image. The study helps eretailers/e-commerce industry to understand customer perception of e-service recovery in India.
\end{abstract}

Keywords: e-tailing, e-service recovery, e-RecS-QUAL, online shopping, India

\section{INTRODUCTION}

The technological evolutions in the recent years have made the retailing as a competitive business environment in the global era. The widespread penetration of internet has been changing the styles and patterns of the retailing sector. The technological innovation of shopping has resulted in customer preference of online purchases rather than from physical retail stores (Wang et al. 2011). The customers have been entered into virtual agreement for online purchases where technology plays a major role than human interaction. People who are more inclined to applications of technology wanted to enjoy online shopping because of flexibility. As a result, the growth of online shopping has been increasing tremendously particularly in India and it is expected to reach $\$ 15$ billion by 2017 . Even though, online retailing industry development has been taking place since the year 2000, still it is the early stage of its development, and India's e-commerce sales are relatively small as compared to U.S. and Europe (Brohan, 2013). Therefore, there is a huge opportunity for the growth of Indian online retailing in the near future.

Online retailing is one of the fastest growing service sectors in India. The sector is more technology driven service and the characteristics of the services may influence the delivery of service at different levels. So, service failure is inevitable and may lead to customer dissatisfaction, disloyalty, and customer switching to competitors. Satisfied customers will communicate their service experience positively to other potential customers, whereas dissatisfied will pass negative word of mouth communication which intern effect the profitability and reputation of the online retailers. Therefore, online retailers should implement ebusiness technologies to streamline the operational efficiency and quality of logistics services of the business processes (Kähkönen et al., 2013, Zakaria, et al., 2010). The implementation of e-business technologies can help online retailers to overcome the major operational challenges such as "logistics, digital infrastructure, payment options, cultural factors, and competitive price" (Kandulapati and Bellamkonda, 2014). The service providers should also focus on formulating effective service recovery policies for building trust on e-tail services to gain competitive advantage. Hence, service recovery plays a vital role and it enables the online retailers to maintain long-term relationships by improving customer satisfaction, loyalty, and retention. Further, the service recovery helps to improve profitability and reputation of the service providers (Kuo and $\mathrm{Wu}, 2012$; Wang et al. 2011; Holloway and Beatty, 2003; Miller et al. 2000).

Despite of many scholarly articles on service failure and service recovery, few of them stressed on the importance of service recovery strategies in relation to customer satisfaction with online retail services. Most of the previous studies ignored to examine the role of service recovery and customer satisfaction for building an image of the online retailer. Hence the study discusses the interdependency among service recovery, customer satisfaction, and image of the online retailer. In this context, the study is following objectives:

- To examine the effect of online service recovery on both customer satisfaction and image of the online retail service provider.

- To measure online service recovery by validating ERecS-QUAL scale developed by Parasuraman et al. (2005) in the context of online retailing in India.

The remainder of this paper consists of the following sections. The first section provides reviews of literature which enables to understand the concepts and interrelationships among service recovery, customer satisfaction and image, and formulation of hypotheses. The 
second section offers the assessment of E-RecS-QUAL scale reliability and validity in the Indian context. The next section validates the proposed hypothesized model of the study. The fourth section examines interrelationships among proposed concepts using structural equation modelling path analysis. The fifth section discusses the results of the study. The final section offers conclusions and direction for future research.

\section{REVIEW OF LITERATURE}

This section reviews the theoretical concepts of this study, including online service recovery, customer satisfaction, and image of the online service providers as well as formulating research hypotheses as follows.

\subsection{Service Recovery}

Service recovery can be defined as "the actions taken by an organization in response to a service failure". Service failure may occur for all kinds of reasons - unavailability of service at the right time, delay of service delivery, service outcome failure, or irresponsibility of employees (Zeithmaml et al. 2010). Service failure in online retailing service can be classified as service delivery, web site layout, online customer service, payment process, security of online transactions (Kuo and Wu, 2012; Holloway and Beatty, 2003). Further, online service failures may take place as pointed by Forbes et al. (2005) as follows: "response to the service delivery system/product failure and response to customer needs and requests". Service providers should try to deliver services promptly right at the first time. But, service failure is inevitable because of the intangible and inseparable nature of services. The service provider can formulate appropriate recovery policies such as "apology and explanation for service failures, refund, free service, gift, discount, and coupon" to convert dissatisfied customers to the state of satisfied customers (Kuo and $\mathrm{Wu}, 2012$ ). Ultimately, the service recovery helps the service provider to retain the customers who have experienced service failure (Miller et al. 2000). Therefore, service recovery practices are more important for online retail service where customers are sensitive to the service failure particularly in India. So, online service recovery refers to the activities and programs designed by online retailer in response to a failure of online service.

\subsection{Dimensions of Online Service Recovery}

The study adopted the E-RecS-QUAL scale developed by Parasuraman et al. (2005). The scale has total 11 items on three dimensions (see appendix):

(i) Responsiveness: this dimension includes five items to measure effectiveness of service problems and return policies

(ii) Compensation: this dimension measures compensation for service failures by three items

(iii) Contact: this dimension has three items to capture how the service provider is available to customers for seeking assistance.

\subsection{Customer Satisfaction, Image and Service Recovery}

According to Anderson and Fornell (1994) satisfaction refers to a function of "perceived quality" and "disconfirmation". Customer satisfaction can be viewed as different perceptive as follows: favourable outcome associated with a purchase or consumption of a product and/or service, comparison of efforts taken and benefits received by customers in a form of purchase outcome and a form of attitude developed based on the transaction-specific measures (Maxham, 2001). In the context of online retail service, customer satisfaction is a transaction-specific measures involved in the process of experiencing the retail service. The literature shows that service recovery has a significant positive effect on customer satisfaction (Collier and Bienstock, 2006; Gustafsson, 2009; Chang and Chang 2010) and the satisfaction can be influenced by the image of the service provider. The image of the service provider is a form of perception in consumers' mind about a company which can be developed over a period of time (Gronroos, 1988). The previous studies proved that there is a significant positive effect of the image of the service provider on customer satisfaction (Lai et al. 2009; Babin et al. 1994; Holbrook, 1994).

\section{HYPOTHESES}

The above section described the review of literature on service recovery, customer satisfaction, and image of the service provider. The review reveals that there is a significant positive effect among all the three constructs: service recovery, customer satisfaction, and image. Accordingly, the study formulated following hypotheses and proposed conceptual model (see Figure 1).

H1. Online service recovery has a significant positive effect on customer satisfaction.

H2. Online service recovery has a significant positive effect on image of online retailer.

H3. The image of the online retailer has a significant positive effect on customer satisfaction.

H4. The image of the online retailer has a mediating effect on the relationship between service recovery and customer satisfaction.

H5. Customer satisfaction has a mediating effect on the relationship between service recovery and image of the online retailer.

H6. The image of the online retailer has a significant positive effect on customer satisfaction.

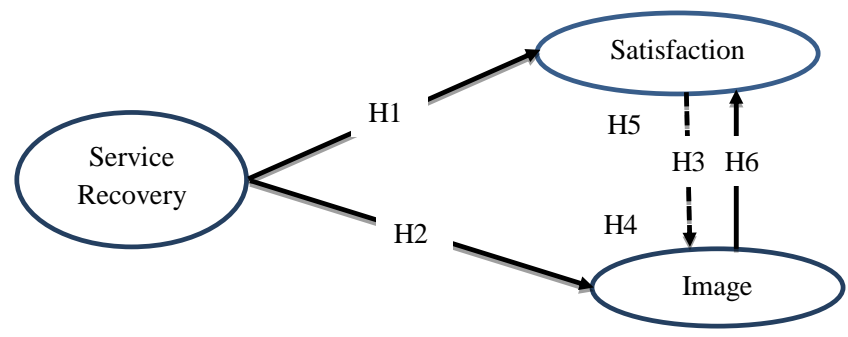

Figure 1 Hypothesized Conceptual Model 


\section{METHODOLOGY}

An online survey was conducted by administering a structured questionnaire to study interrelationships among online service recovery, satisfaction, and image of online retailers in the context of Indian online shopping. The dimensions of E-RecS-QUAL (Parasuraman et al. 2005) are adopted without revision to measure online service recovery of e-retailers. The original 11 items of the E-RecS-QUAL scale along with satisfaction and image items (see appendix) were included in the questionnaire. The data were collected from 140 target respondents (see profiles of the respondents in Table 1) by using purposive sampling method. The respondents were indicated their level of agreement with each of the items on a five-point Likert scale ranging from 1 (strongly disagree) to 5 (strongly agree) and image items from 1 (very low) to 5 (very high). The respondents rated a large variety of online retailers such as eBay who offer a wide range of product categories. The size of the sample met the minimum criteria for conducting factor analysis i.e., the scale item to observation ratio (1:5) (Hair et al. 1998; Stevens 1996).

Table 1 Profiles of the Respondents

\begin{tabular}{|c|c|c|c|}
\hline Variable & Classification & Frequency & $\begin{array}{c}\text { Percentage } \\
\text { (Based on the sample size of } 140 \text { ) }\end{array}$ \\
\hline \multirow{2}{*}{ Gender } & Female & 52 & 37.1 \\
\hline & Male & 88 & 62.9 \\
\hline \multirow{6}{*}{$\begin{array}{l}\text { Age } \\
\text { In years }\end{array}$} & 20 to 25 & 18 & 12.9 \\
\hline & 26 to 30 & 36 & 25.7 \\
\hline & 31 to 35 & 37 & 26.4 \\
\hline & 36 to 40 & 25 & 17.9 \\
\hline & 41 to 50 & 11 & 7.9 \\
\hline & 51 or above & 13 & 9.3 \\
\hline \multirow{3}{*}{ Level of education } & Undergraduate & 4 & 2.9 \\
\hline & Postgraduate & 95 & 67.9 \\
\hline & Doctorate & 41 & 29.3 \\
\hline \multirow{4}{*}{ Occupation } & Student & 27 & 19.3 \\
\hline & Private Employee & 84 & 60 \\
\hline & Government Employee & 21 & 15 \\
\hline & Business owner & 8 & 5.7 \\
\hline \multirow{5}{*}{$\begin{array}{l}\text { Amount of spending on } \\
\text { online purchases per } \\
\text { month (₹) }\end{array}$} & Less than 2000 & 92 & 65.7 \\
\hline & 2001 to 4000 & 31 & 22.1 \\
\hline & 4001 to 6000 & 7 & 5 \\
\hline & 6001 to 8000 & 5 & 3.6 \\
\hline & 8001 and above & 5 & 3.6 \\
\hline
\end{tabular}

The study adopted the following statistical tools for data analysis as: exploratory factor analysis, confirmatory factor analysis, reliability and validity tests, and structural equation modelling. The tools were performed by using SPSS 21 software and Amos 21 software. The following section presents the data analysis of the study.

\section{ANALYSIS}

This section deals with the testing of reliability and validity of E-RecS-Qual scale, and measurement model, and analysis of structural models as explained below.

\subsection{Testing Reliability and Validity of E-RecS- QUAL Scale}

Exploratory factor analysis was performed to explore latent constructs of service recovery scale. The degree of correlations between the variables was significant and it was tested by Bartlett spehericity $\left(\chi^{2}=982.231, \mathrm{p}=0.000\right)$. Further, the KMO value (0.902) exceeds the 0.5 acceptable limits (Hair et al. 1988; Kaizer, 1974) which shows sample adequacy for performing factor analysis. Three latent constructs are extracted from the data, accounting for 82.43 percent of the total variation (see Table 2). The three distinct factors were labelled as: responsiveness (RES), compensation $(\mathrm{COM})$ and contact $(\mathrm{CON})$ as indicated by Parasuraman et al. (1985). The original items RES4 and RES5 of responsiveness dimension were discarded due to cross loading. 


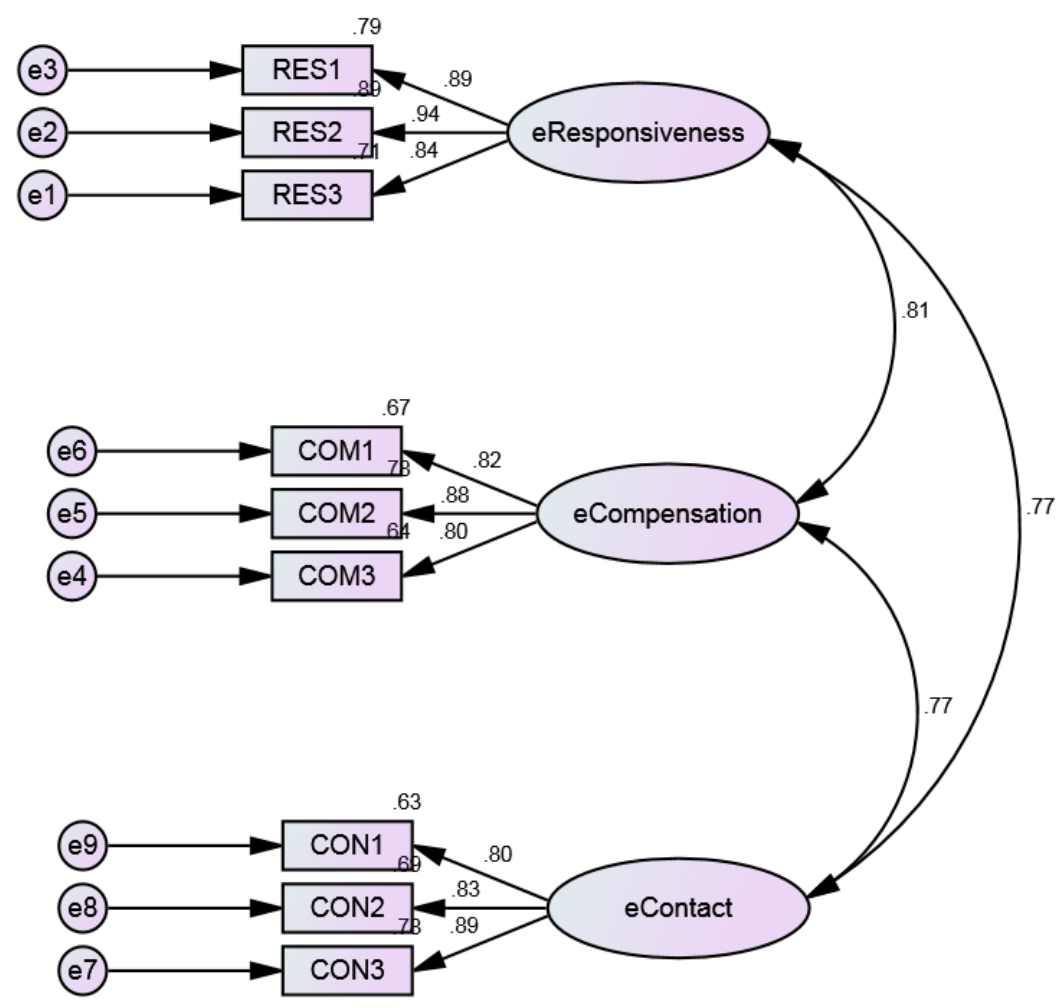

Figure 2 E-RecS-QUAL Measurement Model (CFA)

Table 2 CFA and EFA Results for E-RecS-QUAL Scale

\begin{tabular}{|c|c|c|c|c|c|c|c|c|}
\hline Factor & $\begin{array}{c}\text { CFA } \\
\text { Loadings }^{a}\end{array}$ & t-value* & $\begin{array}{c}\text { EFA } \\
\text { Loadings }^{b}\end{array}$ & AVE & CR & \multicolumn{3}{|c|}{ Inter-construct correlations } \\
\hline & & & & & & RES & $\mathrm{COM}$ & CON \\
\hline & \multicolumn{2}{|c|}{ Responsiveness (RES) } & \multicolumn{3}{|c|}{$($ cronbach $a=0.918)$} & \multirow{4}{*}{1} & \multirow{4}{*}{$0.659 \mathrm{c}$} & \multirow{4}{*}{$0.598^{\circ}$} \\
\hline RES1 & 0.891 & \# & 0.84 & \multirow{3}{*}{0.795} & \multirow{3}{*}{0.921} & & & \\
\hline RES2 & 0.941 & 14.862 & 0.813 & & & & & \\
\hline RES3 & 0.841 & 13.68 & 0.749 & & & & & \\
\hline & \multicolumn{2}{|c|}{ Compensation (COM) } & \multicolumn{2}{|c|}{$($ cronbach $\alpha=0.870)$} & & \multirow{4}{*}{$0.812^{*}$} & \multirow{4}{*}{1} & \multirow{4}{*}{0.599} \\
\hline COM1 & 0.821 & $\#$ & 0.784 & \multirow{3}{*}{0.699} & \multirow{3}{*}{0.875} & & & \\
\hline COM2 & 0.883 & 11.631 & 0.842 & & & & & \\
\hline COM3 & 0.803 & 10.689 & 0.678 & & & & & \\
\hline & \multicolumn{2}{|c|}{ Contact (CON) } & \multicolumn{3}{|c|}{ (cronbach $a=0.875$ ) } & \multirow{4}{*}{$0.773^{*}$} & \multirow{4}{*}{$0.774^{*}$} & \multirow{4}{*}{1} \\
\hline CON1 & 0.797 & \# & 0.837 & \multirow{3}{*}{0.702} & \multirow{3}{*}{0.876} & & & \\
\hline CON2 & 0.83 & 12.185 & 0.742 & & & & & \\
\hline CON3 & 0.885 & 11.443 & 0.798 & & & & & \\
\hline
\end{tabular}

Notes:

1. \# t-value is not estimated, because its value is fixed at $1 .{ }^{*}$ Significant at 0.001 ;

2. EFA-Exploratory factor analysis, CFA-Confirmatory factor analysis, AVE-Average variance extracted, CR-Construct Reliability; * significant at 0.001 .

3. $\quad{ }^{\text {a }}$ Standardized estimates of Amos output;

b Total variance extracted 82.43\%, Extraction Method: Principal Component Analysis, Rotation Method: Varimax with Kaiser Normalization;

${ }^{c}$ Square of inter-construct correlations (below the diagonal values) 
Table 3 Model Fit Summary of E-RecS-QUALl Scale

\begin{tabular}{|c|c|c|c|c|c|c|c|c|c|c|}
\hline \multicolumn{2}{|c|}{} & \multicolumn{4}{|c|}{ Absolute fit indices } & \multicolumn{3}{c|}{ Incremental fit indices } & \multicolumn{3}{c|}{ Parsimony fit indices } \\
\hline $\mathrm{X}^{2^{*}}$ & $\mathrm{df}$ & $\mathrm{X}^{2} / \mathrm{df}$ & $\mathrm{GFI}$ & RMSEA & NFI & TLI & CFI & RFI & AGFI & PNFI \\
\hline 42.25 & 24 & 1.844 & 0.942 & 0.078 & 0.956 & 0.969 & 0.979 & 0.934 & 0.890 & 0.637 \\
\hline
\end{tabular}

Notes:

1. $\quad * \mathrm{p}=0.007$

2. df-degrees of freedom, GFI-Goodness of fit, RMSEA-Root mean square error of approximation; NFI-Normed fit index; RFI-Relative fit index, TLI-Tucker-Lewis index, AGFI-Adjusted goodness of fit; PNFI-Parsimonious normed fit index.

\subsection{Testing Reliability and Validity Assessment of Measurement Model}

The results of the analysis for measurement model are shown in Table 4, Figure 3 and Table 5. As explained in the previous section, the results of measurement analysis also indicate that the model possesses adequate fit, reliability and validity $(\mathrm{CR}>0.7$;
CFA loadings > 0.7; AVE > 0.5; squared inter-construct correlations < AVE; and all the inter-construct correlations are statically significant at 0.001 level). Thus, interrelationships among online service recovery, customer satisfaction and image are reliable and valid for further analysis. So, the next section presents the structural model testing.

Table 4 Model Fit Summary of Research Model of the Study

\begin{tabular}{|c|c|c|c|c|c|c|c|c|c|c|}
\hline \multicolumn{2}{|c|}{} & \multicolumn{4}{c|}{ Absolute fit indices } & \multicolumn{3}{c|}{ Incremental fit indices } & \multicolumn{3}{c|}{ Parsimony fit indices } \\
\hline $\mathrm{X}^{2^{*}}$ & $\mathrm{df}$ & $\mathrm{X}^{2} / \mathrm{df}$ & $\mathrm{GFI}$ & RMSEA & NFI & TLI & CFI & RFI & AGFI & PNFI \\
\hline 62.39 & 32 & 1.95 & 0.919 & 0.83 & 0.928 & 0.948 & 0.963 & 0.898 & 0.861 & 0.660 \\
\hline
\end{tabular}

\section{Notes:}

1. $* \mathrm{p}=0.001$;

2. df-degrees of freedom, GFI-Goodness of fit, RMSEA-Root mean square error of approximation; NFI-Normed fit index; RFI-Relative fit index, TLI-Tucker-Lewis index, AGFI-Adjusted goodness of fit; PNFI-Parsimonious normed fit index.

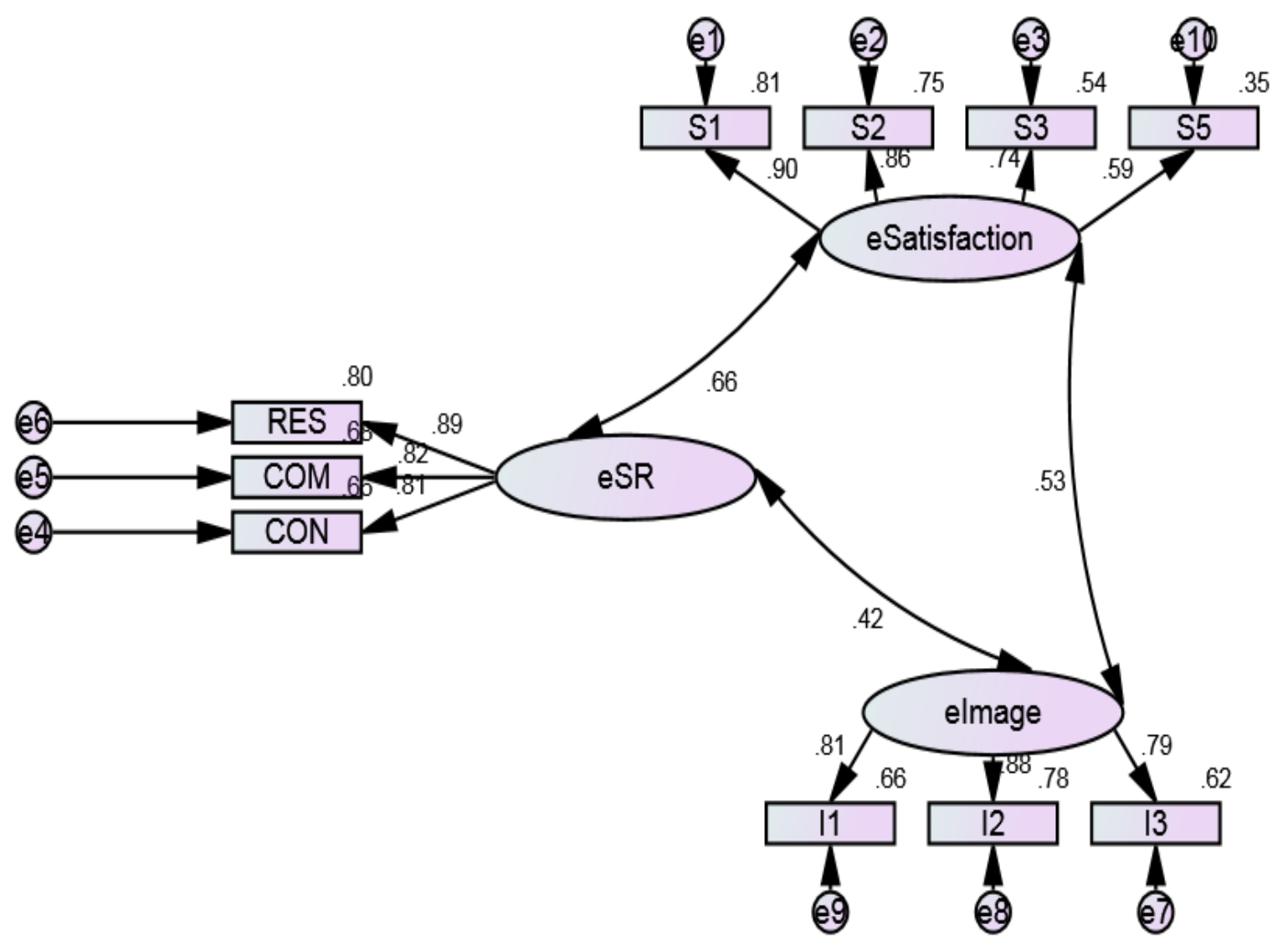

Figure 3 Measurement Model 
Table 5 Results for Measurement Model

\begin{tabular}{|c|c|c|c|c|c|c|c|}
\hline Factor & $\begin{array}{c}\text { CFA } \\
\text { Loadings }^{a}\end{array}$ & t-value & AVE & CR & \multicolumn{3}{|c|}{ Inter-construct correlations } \\
\hline & & & & & eSR & eSatisfaction & elmage \\
\hline \multicolumn{2}{|c|}{ eService recovery (eSR) } & $\operatorname{bach} a=0$ & & & \multirow{4}{*}{1} & \multirow{4}{*}{$0.438^{c}$} & \multirow{4}{*}{$0.180^{c}$} \\
\hline RES & 0.892 & 11.585 & \multirow{3}{*}{0.712} & \multirow{3}{*}{0.881} & & & \\
\hline $\mathrm{COM}$ & 0.823 & 10.753 & & & & & \\
\hline CON & 0.814 & $\#$ & & & & & \\
\hline \multicolumn{2}{|c|}{ eSatisfaction } & $\operatorname{ach} a=0$ & & & \multirow{4}{*}{$0.662^{*}$} & \multirow{4}{*}{1} & \multirow{4}{*}{$0.284^{c}$} \\
\hline S1 & 0.899 & 7.626 & \multirow{3}{*}{0.613} & \multirow{3}{*}{0.861} & & & \\
\hline S2 & 0.865 & 7.497 & & & & & \\
\hline S3 & 0.737 & 6.797 & & & & & \\
\hline S5 & 0.593 & \# & & & & & \\
\hline \multicolumn{2}{|l|}{ elmage } & $\operatorname{ach} \alpha=0$ & & & \multirow{4}{*}{$0.424^{*}$} & \multirow{4}{*}{$0.533^{*}$} & \multirow{4}{*}{1} \\
\hline 11 & 0.812 & 9.962 & \multirow{3}{*}{0.689} & \multirow{3}{*}{0.869} & & & \\
\hline 12 & 0.884 & 10.538 & & & & & \\
\hline 13 & 0.791 & \# & & & & & \\
\hline
\end{tabular}

Notes:

1. \# $\mathrm{t}$-value is not estimated, because its value is fixed at 1 ; *significant at 0.001 ;

2. EFA-Exploratory factor analysis, CFA-Confirmatory factor analysis, AVE-Average variance extracted, CR-Construct Reliability, *significant at 0.001 .

3. " Standardized estimates of Amos output;

b Total variance extracted 82.43\%, Extraction Method: Principal Component Analysis, Rotation Method: Varimax with Kaiser Normalization;

${ }^{\mathrm{c}}$ Square of inter-construct correlations (below the diagonal values)

\subsection{Analysis of the Structural Models}

The study assessed the interrelationships among online service recovery (eSR), satisfaction of the online retail customer (eSatisfaction), and image of the online retail service provider (eImage). The study adopted structural equation modelling and examined the interrelationships in two different viewpoints (see Figure 4, Figure 5 and Table 7).

First, the study examined the effect of service recovery and image on satisfaction (see Figure 4). The study proved that online service recovery has a significant positive effect on both satisfaction and image (support for $\mathrm{H} 1$ and $\mathrm{H} 2$ ), and image on satisfaction (support for H6). This indicates that online service recovery has both direct $(0.573)$ and indirect effect $(0.761)$ on satisfaction. So, online service recovery has a more indirect effect than direct effects. The image of the online retail service provider has a partial mediating effect (support for H4) on the relationship between service recovery and satisfaction in the context of online retailing in India.

Second, the study also examined the effect of service recovery and satisfaction on the image of the online retailer. The study proved that satisfaction of the online retail customer has a full mediating effect (support for H5) on the relationship between online service recovery and image of the online retailer. This indicates that there is a significant direct effect (0.662) of online service recovery on customer satisfaction. Further, customer satisfaction has a direct effect (0.45) on the image of online retailer (support for H3). In this context, there is no significant direct effect of online service recovery on the image of the online retailer.

The assessment of the two structural models reveals that an online retailer having a strong image should focus more on service recovery to improve customer satisfaction. Perhaps, the retailer with a weak image may focus more on improving customer satisfaction by providing effective service recovery practices.

Table 6 Path Analysis

\begin{tabular}{|l|c|c|c|c|l|c|c|c|c|}
\hline \multirow{2}{*}{ Path } & \multicolumn{4}{|c|}{ Structural Model 1 } & \multicolumn{3}{c|}{ Structural model 2 } \\
\cline { 2 - 10 } & Estimate & SRW & C.R. & P & & Estimate & SRW & C.R. & P \\
\hline elmage <--- eSR & 0.317 & 0.424 & 4.376 & $* * *$ & elmage <--- eSR & 0.094 & 0.126 & 1.036 & 0.30 \\
\hline eSatisfaction <--- eSR & 0.573 & 0.531 & 5.920 & $* * *$ & eSatisfaction <--- eSR & 0.714 & 0.662 & 7.400 & $* * *$ \\
\hline eSatisfaction<---elmage & 0.444 & 0.308 & 3.608 & $* * *$ & elmage<---eSatisfaction & 0.312 & 0.450 & 3.582 & $* * *$ \\
\hline
\end{tabular}

\section{Notes:}

1. C.R. $=$ Critical ratio; $\mathrm{SRW}=$ Standardized regression weights; $* * *$ significant at 0.001 


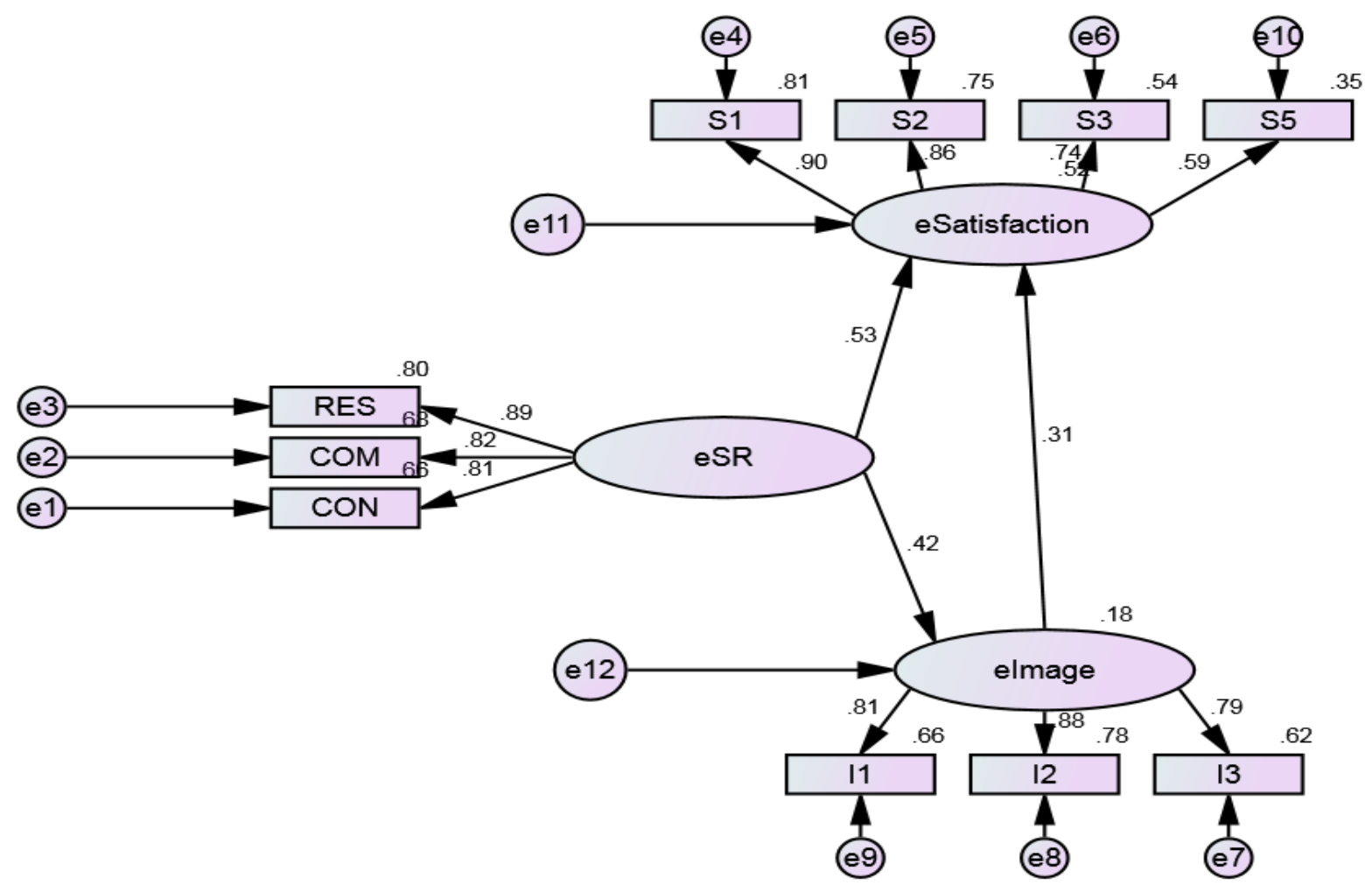

Figure 4 Structural Model 1

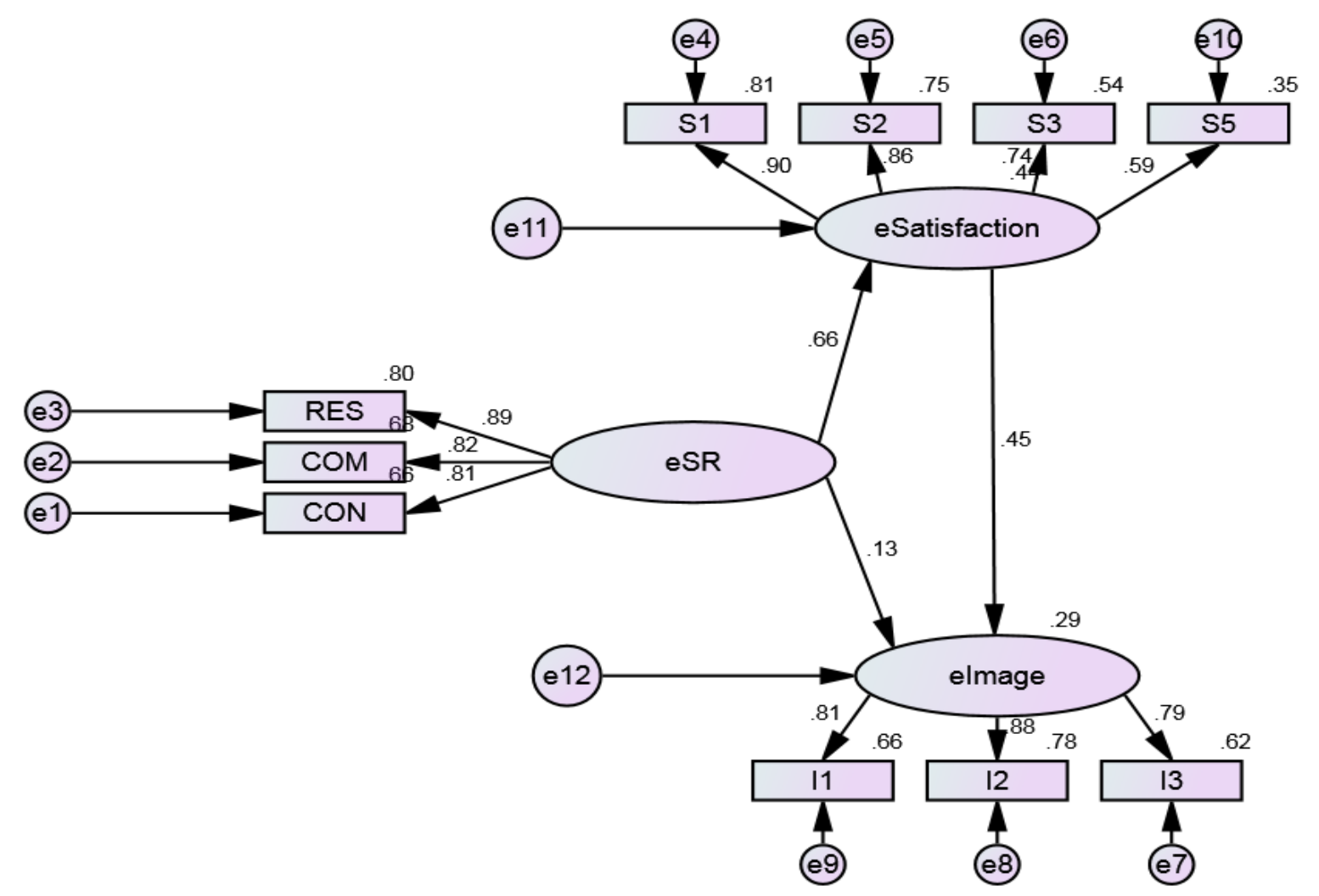

Figure 5 Structural Model 2 


\section{DISCUSSION}

The main purpose of the study is to examine the relationship among online service recovery, customer satisfaction and image of the online retailer. In addition, the study (i) validates the E-RecS-QUAL scale developed by Parasuraman et al., (2005) to measure service recovery in Indian context, (ii) tests the applicability of the model among online retail customers in India and (3) extends the interrelationships into the online service sector. Overall, the study results supported the general applicability of the model in India and in a service setting.

In this study, examining the mediating role of image between online service recovery and customer satisfaction is a key concern. The results reveal the image of online retailer has a significant partial mediating effect of the relationship from online service recovery and customer satisfaction. In addition, there is a direct effect of online service recovery on customer satisfaction, and image on customer satisfaction. This result is consistent with empirical studies showing that service recovery has a significant positive effect on customer satisfaction (Collier and Bienstock, 2006; Gustafsson, 2009; Chang and Chang 2010), and the image has a significant positive effect on customer satisfaction (Lai et al., 2009). Online service recovery has both direct (0.53) and indirect effect $(0.73)$ on customer satisfaction. The majority of the effect of online service recovery on customer satisfaction is indirect (see Figure 4).

The study also, examining the mediating role of customer satisfaction between online service recovery and image of online retailer is a key issue. The results reveal the customer satisfaction has a significant full mediation effect on the relationship between online service recovery and image of the online retailer. In this context, online service recovery has a significant indirect effect (1.11) on the image (see Figure 5).

Hence, the study reveals that the service recovery has both direct and indirect effects on customer satisfaction and image of an online retailer. In case of an online retailer having a strong image has to focus more on online service recovery, on the other hand, an online retailer who has to build image, should focus more both online service recovery and customer satisfaction.

\section{IMPLICATIONS, LIMITATIONS AND DIRECTIONS FOR FURTHER RESEARCH}

The study can help online retailers to understand interrelationships among online service recovery, customer satisfaction, and image of the online retailers. While the study is limited to the Indian context, the results generally emphasize previous studies.

First, service recovery affects both customer satisfaction and image with direct influence. Thus, service recovery is a key determinant for improving customer satisfaction and the image of an online retailer. Second, the image of the online retailer plays a mediating role in improving the customer satisfaction in case of an online retailer having a strong image. Third, if the retailer is at the early stage of its business operations, customer satisfaction affects the image of a company directly and the service recovery affects the image indirectly. But, effective service recovery practices lead to customer satisfaction which in turn leads to the image of the company. Here, customer satisfaction plays a full mediating role in the relationship between service recovery and image of the company.

The major argument of the study is role of customer satisfaction in the relationship between service recovery and image (H3). Even though, it is proved empirically there is no sufficient theoretical support for the same. This is the major limitation of the study which calls for further empirical investigation to support the argument of the study.

\section{CONCLUSION}

This study examines a model incorporating online service recovery, customer satisfaction, and image of the online retailers. The results of the study reveal that E-RecSQUAL developed by Parasuraman et al., (2005) is a reliable and valid scale for measuring online service recovery in the context of India. The study further reveals that online service recovery has a direct effect on both customer satisfaction and image. Finally, customer satisfaction has a full mediating effect on the relationship between the service recovery and image; and image has a partial mediating effect on the relationship between the service recovery and customer satisfaction.

\section{APPENDIX}

\section{E-RecS-QUAL Scale (adopted from Parasuraman et al., 2005)}

Respondents rated the online retail service provider on each scale item using a 5-point scale ( $1=$ strongly disagree, $5=$ strongly agree $)$ and $(1=$ very low, $5=$ very high $)$. The image was rated using a 5 -point scale $(1=$ very low, $5=$ very high). The symbols preceding the items correspond to the variable names in the body of the paper.

\section{Responsiveness}

RES1 It provides me with convenient options for returning items.

RES2 This site handles product returns as well.

RES3 This site offers a meaningful guarantee.

RES4 It tells me what to do if my transaction is not processed.

RES5 It takes care of problems promptly.

\section{Compensation}

COM1 This site compensates me for the problems it creates. COM2 It compensates me when what I ordered doesn't arrive on time.

COM3 It picks up items I want to return from my home or business.

\section{Contact}

CON1 This site provides a telephone number to reach the company.

CON2 This site has customer service representatives available online.

CON3 It offers the ability to speak to a live person if there is a problem.

Satisfaction (adopted from Lai et al., 2009)

SA1. I am satisfied with the services I receive from the site 
SA2. Overall, I am satisfied with the site

SA3. I enjoy online shopping

SA4. I feel online shopping is risk taking

SA5. Overall, my online shopping experience is good.

Image (adopted from Lai et al., 2009)

I1. Please rate reputation of your favourite online shopping site

I2. Please rate prestige of your favourite online shopping site

I3. Please rate the reputation of products and services of the site

\section{REFERENCES}

Anderson, E. W., Fornell, C., \& Lehmann, D. R. (1994), Customer satisfaction, market share, and profitability: findings from Sweden, The Journal of Marketing, pp. 53-66.

Babin, B. J., Darden, W. R., \& Griffin, M. (1994), Work and/or fun: measuring hedonic and utilitarian shopping value. Journal of Consumer Research, pp. 644-656.

Brohan (2013), "India's online retail market could double in size", January $11, \quad$ available at:http://www.internetretailer.com/2013/01/11/indias-onlineretail-market-could-double-size, (accessed on 24 September 2013).

Chang, Y. W., \& Chang, Y. H. (2010), Does service recovery affect satisfaction and customer loyalty? An empirical study of airline services. Journal of Air Transport Management 16 (6), pp. 340-342.

Collier, J. E., \& Bienstock, C. C. (2006), Measuring service quality in e-retailing, Journal of Service Research 8 (3), pp. 260-275.

Cronbach, R.G. (1960), Essentials of Psychological Testing, 2nd Ed., Harper and Row Company, New York, NY.

Fornell, C., \& Larcker, D. F. (1981), Evaluating structural equation models with unobservable variables and measurement error. Journal of Marketing Research, pp. 39-50.

Gerbing, D. W., \& Anderson, J. C. (1988), An updated paradigm for scale development incorporating unidimensionality and its assessment, Journal of Marketing Research, pp. 186-192.

Grönroos C. (1988), Service quality: the six criteria of good perceived service quality. Rev Bus. 9 (3), pp. 10-3.

Gustafsson, A. (2009), Customer satisfaction with service recovery, Journal of Business Research 62 (11), pp. 12201222.

Hair, J.F., Anderson, R.E., Tatham, R.L. and Black, W.C. (1998), Multivariate Data Analysis, 5th Ed., Prentice-Hall Inc., Upper Saddle River, NJ.

Hair, J. F., Black W, Babin, B. J., Anderson, R. E., Tatham, R. L. (2006). Multivariate Data Analysis. 6th edition. Upper Saddle River, New Jersey: Prentice Hall.
Holbrook, M. B. (1994), The nature of customer value: an axiology of services in the consumption experience, Service quality: New directions in theory and practice 21.

Holloway, B. B., \& Beatty, S. E. (2003), Service Failure in Online Retailing A Recovery Opportunity, Journal of Service Research 6 (1), pp. 92-105.

Holloway, B. B., Wang, S., \& Parish, J. T. (2005), The role of cumulative online purchasing experience in service recovery management, Journal of Interactive Marketing, 19 (3), pp. 54-66.

Kähkönen, A. K., Lintukangas, K., \& Virolainen, V. M. (2013), The Effects of e-Business on Supply Management. Operations and Supply Chain Management 6 (2), pp. 75-84.

Kaizer, H.F. (1974), An index of factorial simplicity, Psychometrika 39 (1), pp. 31- 36.

Kandulapati, S., \& Bellamkonda, R. S. (2014), E-Service Quality: a study of online shoppers in India, American Journal of Business 29 (2).

Kuo, Y. F., \& Wu, C. M. (2012), Satisfaction and post-purchase intentions with service recovery of online shopping websites: Perspectives on perceived justice and emotions, International Journal of Information Management 32 (2), pp. 127-138.

Lai, F., Griffin, M., \& Babin, B. J. (2009), How quality, value, image, and satisfaction create loyalty at a Chinese telecom, Journal of Business Research 62 (10), pp. 980-986.

Miller, J. L., Craighead, C. W., \& Karwan, K. R. (2000), Service recovery: a framework and empirical investigation, Journal of Operations Management 18 (4), pp. 387-400.

Maxham III, J. G. (2001), Service recovery's influence on consumer satisfaction, positive word-of-mouth, and purchase intentions, Journal of Business Research 54 (1), pp. 11-24.

Nunnally, J.C. (1967), Psychometric Theory, 1st ed., McGraw-Hill, New York, NY.

Parasuraman, A., Zeithaml, V. A., \& Malhotra, A. (2005), ESQUAL a multiple-item scale for assessing electronic service quality, Journal of Service Research 7 (3), pp. 213-233.

Patterson, P. G., Cowley, E., \& Prasongsukarn, K. (2006), Service failure recovery: the moderating impact of individual-level cultural value orientation on perceptions of justice, International Journal of Research in Marketing 23 (3), pp. 263-277.

Wang, Y. S., Wu, S. C., Lin, H. H., \& Wang, Y. Y. (2011), The relationship of service failure severity, service recovery justice and perceived switching costs with customer loyalty in the context of e-tailing, International Journal of Information Management 31 (4), pp. 350-359.

Zakaria, H., Zailani, S., \& Fernando, Y. (2010), Moderating role of logistics information technology on the logistics relationships and logistics service quality, Operations and Supply Chain Management 3 (3), pp. 134-147.

Zeithaml, V. A., Gremler, D. D., Bitner, M. J., \& Pandit, A. (2010). Services marketing: integrating customer focus across the firm, 4th ed., TMH, New Delhi.

Suresh Kandulapati obtained an MBA (Marketing) from Jawaharlal Nehru Technological University Campus, Hyderabad in the year 2005, and M.Phil from Sri Venkateswara University, Tirupati in the year 2009. Nudging a total 7 years of experience in academics and research, he is presently pursuing a full-time Ph.D. (Management Studies) from School of Management Studies, University of Hyderabad. Service quality, mobile services, online retailing, customer engagement, and employee engagement are his major areas of research.

Raja Shekhar did his Bachelor's Degree in Civil Engineering from Acharya Nagarjuna University and Master's in Business Administration from Osmania University. Subsequently, Prof. Shekhar was awarded a Doctorate degree in Business Management by Kakatiya University. Nudging a total of 20 years of experience in academics, research and administration, presently he is the Registrar, University of Hyderabad. His primary areas of interests include Service Quality, Quantitative Techniques, Research Methodology and Project Management. 